\title{
Effects of Levamisole on Normal and Abnormal
}

\section{Leukocyte Locomotion}

\author{
Daniel G. Wright, Charles H. KirkPatrick, and John I. Gallin \\ From the Clinical Physiology Section and the Clinical Allergy and Hypersensitivity Section of the \\ Laboratory of Clinical Investigation, National Institute of Allergy and Infectious Diseases, \\ National Institutes of Health, Bethesda, Maryland 20014
}

A B S TRACT The anti-helminthic drug levamisole hydrochloride has been reported to stimulate immune responses in humans and experimental animals. We have investigated levamisole effects on human leukocyte locomotion in vitro in studies of neutrophils and mononuclear cells from normal adults, from patients with Chediak-Higashi disease and from patients with the syndrome of hyperimmunoglobulin E, recurrent pyogenic infections, and defective leukocyte chemotaxis. Directed migration (chemotaxis) of neutrophils and mononuclear cells from normal adults and from the hyperimmunoglobulin $\mathrm{E}$ syndrome patients, but not from Chediak-Higashi patients, were stimulated by levamisole at concentrations of 0.01-1.0 $\mu \mathrm{M}$, with stimulation observed most consistently at $0.1 \mu \mathrm{M}$. These concentrations of drug also increased cyclic GMP levels in mononuclear cells and enhanced hexose monophosphate shunt activity in neutrophils, but did not alter chemotactic factor-induced changes in the surface charge of neutrophils. Other concentrations of levamisole did not affect leukocyte locomotion except for a high concentration $(5.0 \mathrm{mM})$ which stimulated both random and directed leukocyte migration.

When patients with the hyperimmunoglobulin $\mathrm{E}$ syndrome took levamisole by mouth, the abnormal chemotactic responses of their neutrophils were significantly improved towards normal. These studies are the first to show pharmacologic improvement of in vitro leukocyte locomotion in patients in whom recurrent infections have been attributed to a defect of this leukocyte function.

Portions of this report have appeared in abstract form in 1976. Clin. Res. 24: 455A.

Received for publication 2 February 1976 and in revised form 24 January 1977.

\section{INTRODUCTION}

Levamisole hydrochloride has been used widely in veterinary and in human medicine as an anti-helminthic, particularly for nematode infections (1-3). However, there has been recent interest in possible effects of this drug on immune responses and in immune deficiency. Various functions of lymphocytes and of phagocytic cells have been reported to be enhanced by levamisole (4-14) and these findings have encouraged the trial of this drug in patients with suspected host defense defects (14-16).

While directed migration of leukocytes (chemotaxis) has long been thought to be important in immune responses, reproducible techniques for measuring this leukocyte function in vitro are recent developments (17). Reports of abnormal leukocyte chemotaxis in patients with syndromes of recurrent infections are also recent (18).

In these studies we have investigated the effects of levamisole on the locomotion of human neutrophils and mononuclear cells from normal adults and from patients with syndromes characterized by defective leukocyte chemotaxis and recurrent bacterial infections. These studies show that levamisole increases the chemotactic responses of both normal and abnormal leukocytes at concentrations which may be achieved in vivo after oral administration.

\section{METHODS}

\section{Human subjects}

Healthy adults of both sexes donated blood from which leukocytes were obtained to define normal leukocyte function with and without levamisole.

Studies with abnormal leukocytes involved two brothers, 
TABLE I

Patients with Recurrent Pyogenic Infections and Hyperimmunoglobulin E

\begin{tabular}{|c|c|c|c|c|c|}
\hline Patient & Age $^{*} /$ Sex & Race & Infections & IgE & Other findings \\
\hline & & & & $n g / m l t$ & \\
\hline $\mathbf{A}$ & $25 / M$ & White & $\begin{array}{l}\text { Many pneumonias, lung } \\
\text { abscesses, skin and node } \\
\text { abscesses, pelvic } \\
\text { abscess, peritonitis }\end{array}$ & 17,500 & $\begin{array}{l}\text { Mucocutaneous } \\
\text { candidiasis }\end{array}$ \\
\hline B & $12 / \mathrm{F}$ & Black & $\begin{array}{l}\text { Many pneumonias, } \\
\text { lung abscess, skin } \\
\text { and node abscesses }\end{array}$ & 37,000 & Eczema \\
\hline C & $16 / F$ & Black & $\begin{array}{l}\text { Pneumonia with empyema } \\
\text { chronic furunculosis, } \\
\text { chronic keratocon- } \\
\text { junctivitis }\end{array}$ & 2,400 & - \\
\hline D & $16 / F$ & White & $\begin{array}{l}\text { Many pneumonias with } \\
\text { empyema, osteomyelitis, } \\
\text { skin and node abscesses }\end{array}$ & 40,000 & $\begin{array}{l}\text { PInfantile eczema, } \\
\text { mucocutaneous } \\
\text { candidiasis }\end{array}$ \\
\hline
\end{tabular}

* Age at the time of the present studies.

† IgE measurement in nanograms per milliliter (Phadebas IgE, Pharmacia Fine Chemicals, Inc.) at the time of the present studies; normal range, 50-500 (mean 105).

aged 21 and $25 \mathrm{yr}$, with Chediak-Higashi (C-H $)^{1}$ disease, both of whom have been described in previous clinical reports (19). The chemotactic responses of their neutrophils (20) and mononuclear cells (21) have been shown to be markedly impaired. Both patients have had recurrent pyogenic infections throughout their lives.

In addition, four patients with recurrent pyogenic infections and consistently elevated levels of serum IgE were studied. Abnormal neutrophil and mononuclear cell chemotaxis have been found consistently in these patients during follow-up at the National Institutes of Health for 9 mo to $5 \mathrm{yr}$. Two patients (patient D [22, 23] and patient B [24], Table I) have been subjects of case reports in which these abnormalities were described. Each of these patients has suffered from bacterial abscesses and pneumonias requiring multiple drainage procedures. Lymphocytes from these patients have shown impaired transformation responses to antigens in vitro as reported by others in comparable patients (25). Clinical features of these four patients are summarized in Table $\mathrm{I}$. The syndrome, represented by these patients and described by several authors, lacks a generally recognized eponym (reviewed in 25), and for convenience, we have used the term hyperimmunoglobulin $\mathrm{E}$ (HIE) syndrome in referring to these patients.

\section{Levamisole}

Levamisole hydrochloride, the levo-rotatory enantiomere of tetramisole, was obtained from Janssen $R$ and D, New Brunswick, N. J. The purity of this synthetic compound (mol wt 240.75; lot no. SM17311) was determined by the manufacturer to be greater than $99 \%$ with spectrophotometric methods. For in vitro studies, the drug was dissolved in

${ }^{1}$ Abbreviations used in this paper: cAMP, cyclic adenosine monophosphate; cGMP, cyclic guanosine monophosphate; C-H, Chediak-Higashi; HIE, hyperimmunoglobulin E.
$0.85 \%$ saline to appropriate concentrations immediately before use. Leukocytes were exposed in vitro to levamisole or to saline alone in media that contained no more than $10 \%$ levamisole solution or saline.

For certain studies, patients were given levamisole by mouth. Levamisole tablets used in these studies contained $50 \mathrm{mg}$ levamisole $\mathrm{HCl}, 42 \mathrm{mg}$ cellulose, $7 \mathrm{mg}$ lactose, 1.7 mg Sterotex, and $0.3 \mathrm{mg} \mathrm{SiO}$. Patients took levamisole in a single dose of $150 \mathrm{mg}$ on two successive days in accordance with a protocol approved by the National Institute of Allergy and Infectious Diseases Clinical Research Committee.

\section{Measurement of leukocyte migration}

Neutrophils. Neutrophil directed migration (chemotaxis) and random migration were measured in vitro with a radioassay that employs ${ }^{51} \mathrm{Cr}$-labeled neutrophils and double micropore filter chemotactic chambers (26), and with a morphologic assay in which the distance migrated into a micropore filter is assessed (27). For the first assay, human leukocytes were separated from heparinized blood by dextran sedimentation (Dextran T250, Pharmacia Fine Chemicals Inc., Uppsala, Sweden). Leukocytes were then labeled with chromium-51 $\left({ }^{51} \mathrm{Cr}\right.$, sodium chromate, Amersham Searle Corp., Arlington Heights, Ill.) and placed in the upper compartment of a modified Boyden chamber that was separated from a lower compartment by two 3- $\mu \mathrm{m}$ micropore cellulose nitrate filters (Sartorius, Beckman Instruments Inc., Science Essentials Co., Mountainside, N. J.). The labeled cells were suspended at a concentration of $2.3 \times 10^{8}$ neutrophils $/ \mathrm{ml}$ in Gey's medium (containing $2 \%$ bovine serum albumin, penicillin and streptomycin, Microbiological Associates, Bethesda, Md.) that had been mixed 9:1 with saline or with a levamisole solution. Although leukocyte assay systems were well buffered, the addition of high concentrations of levamisole $(5.0 \mathrm{mM})$ lowered the $\mathrm{pH}$ slightly (from 7.3 to 7.1 ); other concentrations of drug tested $(0.01 \mu \mathrm{M}$ to $0.1 \mathrm{mM})$ did not cause measura- 
ble $\mathrm{pH}$ changes. In certain experiments, the $\mathrm{pH}$ of the cell suspensions that did not contain levamisole were varied with $\mathrm{HCl}$.

In assays of directed migration a chemotactic stimulus was added to the lower compartment of the chemotactic chambers. It has been shown previously that only neutrophils migrate into the lower filter during incubation periods of up to $3 \mathrm{~h}$ in $100 \%$ humidity and $5 \% \mathrm{CO}_{2}$, and that the number of migrating neutrophils is proportional to the radioactivity incorporated into the lower filter (26). To assess spontaneous random migration of the leukocytes, Gey's medium alone was added to the lower compartment of the assay chambers. In related experiments, equal concentrations of a chemotactic stimulus were added to both upper and lower compartments of the chambers. This experimental condition permitted an assessment of the stimulated or activated random migration which occurs when leukocytes are exposed to a chemotactic stimulus without a concentration gradient. After adjusting for variability in specific activity and incorporation of the ${ }^{51} \mathrm{Cr}$ by neutrophils, migration was expressed as corrected counts per minute in the lower filter (26). In all studies results of each experimental condition represented means of quadruplicate determinations.

For the morphologic assay essentially pure preparations of human neutrophils were separated from heparinized blood by the use of Hypaque-Ficoll gradients (Hypaque-M 90\%, Winthrop Laboratories, New York; Ficoll-400, Pharmacia Fine Chemicals Inc.,) (28), followed by dextran sedimentation. Neutrophils were suspended at a concentration of $2.3 \times 10^{6} / \mathrm{ml}$ in Gey's medium and were placed in the upper compartments of modified Boyden chambers. A single $3-\mu \mathrm{m}$ cellulose nitrate filter separated the upper and lower compartments of the chambers. Again, experimental conditions designed to compare spontaneous random migration, activated random migration, and directed migration (chemotaxis) were studied concurrently. After $\mathbf{4 5} \mathrm{min}$ of incubation, the filters were removed, fixed in methanol, stained in Meyer's hematoxylin and eosin, dehydrated with increasing concentrations of ethanol, and cleared with xylene. Filters were then examined microscopically with $45 \times$ objective and $10 \times$ ocular lenses. Migration fronts were determined by measuring the micrometers from the top of each filter to the farthest distance traveled by two cells per high power field. Five such measurements were made from each filter $(27,29)$. The measurements from duplicate filters were pooled, and means and standard errors determined. Cells were also counted at different levels in the filters by focusing at $15-\mu \mathrm{m}$ intervals beginning at the top of the filters. At each focal plane, cells were counted in each of four separate fields. Cell counts from duplicate filters were combined and the means and standard errors determined (29).

In these studies, two chemotactic stimuli were used: endotoxin activated serum (fresh normal serum incubated with Escherichia coli lipopolysaccharide B 0127:B8, Difco Laboratories, Detroit, Mich. (30) and casein (sodium caseinate, Difco Laboratories). Activated serum preparations contained $2.5 \%$ serum in the final stimulus solutions; casein solutions contained $5 \mathrm{mg} / \mathrm{ml}$ sodium caseinate in $0.85 \%$ saline.

Mononuclear cells. Mononuclear cell migration was tested by means of a previously described morphologic assay (31). Human mononuclear cells were separated from heparinized blood by use of Hypaque-Ficoll gradients and suspended in Gey's medium at a concentration of $2.3 \times 10^{6} \mathrm{cells} / \mathrm{ml}$. The same chemotactic chambers used to measure neutrophil migration were used in this assay except that a single 5- $\mu \mathrm{m}$ pore polycarbonate filter (Neuro Probe, Inc. Bethesda, Md.) separated the two chamber compartments. Endotoxin-activated normal serum was used as the chemotactic stimulus. Experimental conditions for spontaneous random migration, activated random migration, and directed migration were again compared. After incubation of cells and stimuli for $90 \mathrm{~min}$ at $37^{\circ} \mathrm{C}$ in $100 \%$ humidity and $5 \% \mathrm{CO}_{2}$, the filters were removed, fixed, and stained. Cells that had migrated to the undersides of the filters were counted in five separate high power fields (21). These counts were averaged and results were expressed as cells/ high power field. Each experimental condition was done in quadruplicate, and in each experiment means and standard errors were computed from these quadruplicate measurements.

\section{Measurement of hexose monophosphate shunt activity in neutrophils}

Preparations of human leukocytes containing 95-98\% neutrophils were obtained from heparinized blood as described above. Metabolism of ${ }^{14} \mathrm{C}_{1}$-glucose (New England Nuclear, Boston, Mass.) to ${ }^{14} \mathrm{CO}_{2}$ by neutrophils at a concentration of $2.5 \times 10^{6}$ cells $/ \mathrm{ml}$ was measured (32). Resting and phagocytizing neutrophils (incubated with $1.1-\mu \mathrm{m}$ diameter latex particles; Dow Diagnostics, The Dow Chemical Co., Indianapolis, Ind., 100 particles: 1 neutrophil) were incubated with and without levamisole. Results are expressed as nanomoles ${ }^{14} \mathrm{C}_{1}$-glucose metabolized/1 h incubation of cells.

\section{Measurement of cellular cyclic nucleotides}

Cyclic adenosine monophosphate (cAMP) and cyclic guanosine monophosphate (cGMP) levels in neutrophils and in mononuclear cells were measured by radioimmunoassay as described previously $(33,34)$. Preparations of neutrophils and mononuclear cells were obtained as described above. Preliminary experiments showed that no effects of levamisole on cyclic nucleotide accumulation were detectable unless the cells were incubated in the presence of imidazole $(0.01$ $\mu \mathrm{M})$. Imidazole by itself did not significantly raise cyclic nucleotide levels in the absence of other stimuli. In the experiments reported here, cells were preincubated for 15 min at $37^{\circ} \mathrm{C}$ in media with $0.01 \mu \mathrm{M}$ imidazole (Sigma Chemical Co., St. Louis, Mo.). The requirement for imidazole in test conditions for measurable recoveries of cyclic nucleotides has been noted by others (8). Test substances were then added to the leukocytes, and the incubation was continued for an additional $5 \mathrm{~min}$. The reaction was stopped by the addition of cold $10 \% \mathrm{HClO}_{4}$, and the cells were homogenized and the resulting lysates neutralized with $\mathrm{KOH}$. The extracts were applied to columns of Bio-Rad AG-1X8 formate (Bio-Rad Laboratories, Richmond, Calif.) which were then washed with $0.1 \mathrm{~N}$ formic acid. cAMP was eluted with $2 \mathrm{~N}$ formic acid and cGMP was eluted with $4 \mathrm{~N}$ formic acid. After lyophilization to remove formic acid, the cyclic nucleotides were radioimmunoassayed with commercial reagents (Collaborative Research, Waltham, Mass.). Trace amounts of $\left[{ }^{3} \mathrm{H}\right] \mathrm{cAMP}$ or $\left[{ }^{3} \mathrm{H}\right] \mathrm{cGMP}$ were added to the cell homogenates before application on the columns. Recovery of cAMP was 45-50\% and cGMP, 30-35\%. Data presented in the results have been corrected for recoveries observed in each individual experiment.

\section{Measurement of neutrophil surface charge}

The surface charge of human leukocytes was measured with a modification of a reported electrophoretic mobility assay (35). Human neutrophils were separated from heparinized blood by use of Hypaque-Ficoll gradients and dex- 
TABLE II

Neutrophil Migration Responses with and without Levamisole

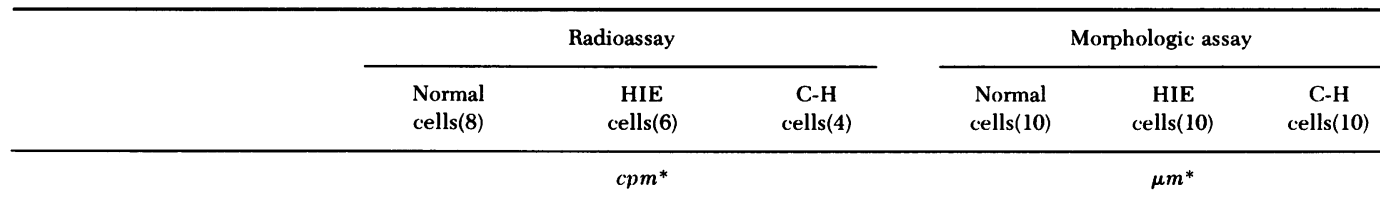

A. Normal and abnormal neutrophil migration responses

Directed migration $\$$

$\begin{array}{ccccccr}\begin{array}{c}\text { (chemotaxis) } \\ \text { Activated random }\end{array} & 1,233 \pm 110 & 693 \pm 109 & 120 \pm 31 & 128 \pm 2.9 & 103 \pm 2.3 & 69 \pm 3.5 \\ \begin{array}{c}\text { migration } \ddagger \\ \begin{array}{c}\text { pontaneous random } \\ \text { migration } \ddagger\end{array}\end{array} & 287 \pm 42 & 115 \pm 12 & 98 \pm 13 & 102 \pm 2.4 & 85 \pm 3.1 & 54 \pm 6.2 \\ & 120 \pm 28 & 114 \pm 18 & 86 \pm 6 & 73 \pm 2.3 & 70 \pm 1.7 & 39 \pm 4.1\end{array}$

B. Effects of levamisole on neutrophil directed migration (chemotaxis)

Directed migration $\ddagger$

\begin{tabular}{|c|c|c|c|c|c|c|}
\hline $\begin{array}{l}\text { Without drug } \\
\text { With levamisole }\end{array}$ & $1,233 \pm 110$ & $693 \pm 109$ & $120 \pm 31$ & $128 \pm 2.9$ & $103 \pm 2.3$ & $69 \pm 3.5$ \\
\hline $0.01 \mu \mathrm{M}$ & $1,327 \pm 63$ & $805 \pm 129$ & $105 \pm 18$ & $133 \pm 4.7$ & $107 \pm 3.4$ & $65 \pm 5.1$ \\
\hline $0.1 \mu \mathrm{M}$ & $1,589 \pm 729$ & $1,229 \pm 1439$ & $128 \pm 35$ & $146 \pm 1.49$ & $132 \pm 3.19$ & $67 \pm 3.2$ \\
\hline $1.0 \mu \mathrm{M}$ & $1,302 \pm 252$ & $1,100 \pm 125 \pi$ & $126 \pm 22$ & $139 \pm 4.29$ & $115 \pm 2.8 \pi$ & $70 \pm 2.8$ \\
\hline $0.1 \mathrm{mM}$ & $1,191 \pm 161$ & $950 \pm 176$ & $235 \pm 85$ & $126 \pm 5.2$ & $105 \pm 4.2$ & $75 \pm 4.1$ \\
\hline $5.0 \mathrm{mM}$ & $2,055 \pm 2339$ & $1,510 \pm 145$ & $276 \pm 719$ & $155 \pm 4.39$ & $128 \pm 5.0$ ㅇ & $81 \pm 4.39$ \\
\hline
\end{tabular}

C. Effects of levamisole on neutrophil activated random migration

Activated random

migration $\ddagger$

Without drug

With levamisole $\$$

\begin{tabular}{|c|c|c|c|c|c|c|}
\hline $0.01 \mu \mathrm{M}$ & $405 \pm 67$ & $221 \pm 30$ ग & $103 \pm 17$ & $103 \pm 2.2$ & $86 \pm 2.5$ & $58 \pm 4.1$ \\
\hline $0.1 \mu \mathrm{M}$ & $481 \pm 449$ & $239 \pm 289$ & $95 \pm 14$ & $121 \pm 2.3$ & $114 \pm 5.4 \pi$ & $53 \pm 3.6$ \\
\hline $1.0 \mu \mathrm{M}$ & $419 \pm 76$ & $127 \pm 18$ & $99 \pm 4$ & $119 \pm 2.39$ & $108 \pm 2.5$ & $55 \pm 5.3$ \\
\hline $0.1 \mathrm{mM}$ & $311 \pm 64$ & $121 \pm 22$ & $106 \pm 19$ & $124 \pm 2.4 \pi$ & $87 \pm 1.3$ & $62 \pm 3.7$ \\
\hline $5.0 \mathrm{mM}$ & $503 \pm 43 \pi$ & $384 \pm 43$ & $167 \pm 249$ & $134 \pm 5.29$ & $119 \pm 2.59$ & $83 \pm 5.19$ \\
\hline
\end{tabular}

Number of determinations is in parentheses.

* Migration responses expressed as corrected counts per minute lower filter \pm standard error of the mean, 3-h incubations (radioassay) and as $\mu \mathrm{m}$ migrated by leading front of cells \pm standard error of the mean, 45-min incubations (morphologic assay).

$\ddagger$ Directed migration (chemotaxis) $=2.5 \%$ endotoxin-activated serum in the stimulus compartment of the assay chambers; activated random migration $=2.5 \%$ endotoxin-activated serum in both stimulus and cell compartments of the assay chambers; spontaneous random migration = buffer alone in stimulus compartment of assay chambers.

$\$$ Concentration of levamisole with cells during assay.

I Difference between migration of levamisole-treated cells and migration of cells without drug is significant, $P<0.05$, Student's $t$ test.

tran sedimentation (28). The neutrophils were then washed three times in modified Hank's solution and resuspended in this solution with or without levamisole. Partially purified C5a obtained by Sephadex chromatography or endotoxinactivated serum (30) or the eluting buffer alone, used in the C5a preparation, was added to the cells. The cells (3.0 $\times 10^{6} / \mathrm{ml}$ ) were then incubated at $37^{\circ} \mathrm{C}$ for $30 \mathrm{~min}$. After incubation, the cells were washed twice in $0.13 \mathrm{M}$ phosphate$5 \%$ sorbitol (pH 7.2) and suspended in the phosphate sorbitol buffer at a concentration of $3.0 \times 10^{6} / \mathrm{ml}$. The electrophoretic mobility was determined by a cytopherometer with platinum electrodes (Carl Zeiss, Inc., New York). All measurements were made in the frontal plane at $23^{\circ} \mathrm{C}$, and for each experimental point 20 determinations were made on 10 different cells with the second measurement of each cell made after reversal of polarity. Neutrophil surface charge was calculated as described previously and expressed as micrometers per second per volt per centimeter (35).

\section{RESULTS}

Random and directed migration of neutrophils from patients and from normal volunteers. The abnormal random and directed migration of neutrophils from patients with $\mathrm{C}-\mathrm{H}$ disease and from patients with $\mathrm{HIE}$ syndrome is shown in Table II (Section A). Directed 
migration (chemotaxis) of neutrophils from the C-H and the HIE patients was significantly less than normal $(P<0.01$, Students' $t$ test $)$. The spontaneous random migration of $\mathrm{C}-\mathrm{H}$ neutrophils was also less than normal, as reported previously (20), while the spontaneous random migration of HIE neutrophils was not depressed. However, the activated random migration of leukocytes from both patient groups was significantly abnormal $(P<0.01)$.

Effects of levamisole on neutrophil migration in vitro. Levamisole at concentrations of 0.01-1.0 $\mu \mathrm{M}$ significantly enhanced the directed migration (chemotaxis) of neutrophils from both normal donors and patients with the HIE syndrome. The concentration producing the peak effect varied with different donors, but as shown by the pooled data of Table II (Section B) enhancement was seen most consistently at $0.1 \mu \mathrm{M}$. These concentrations of levamisole also stimulated activated random migration of leukocytes from normal individuals and from HIE patients (Table II, Section C). In contrast, neutrophils from C-H patients did not show increased directed or activated random migration in the presence of 0.01-1.0 $\mu \mathrm{M}$ levamisole (Table II, Sections B and C). Moreover, these concentrations of drug did not affect the spontaneous random migration of neutrophils from any of the patients or normal donors (data not shown).

Higher concentrations of levamisole (above $0.1 \mathrm{mM}$ ) enhanced the migration responses of neutrophils from all patients and normal donors. Not only did $5.0 \mathrm{mM}$ levamisole increase the directed migration of normal and abnormal neutrophils (Table II, Section B), but it also uniformly increased activated random migration (Table II, Section C) as well as spontaneous random migration (data not shown). However, levamisole did not possess intrinsic chemotactic activity at any concentration; that is, when drug was present in the stimulus compartment of the chemotactic chambers, migration of cells was not greater than that observed when drug was in the cell compartment or in both compartments of the chambers.

Stimulation of the directed migration of normal and HIE neutrophils by the lower concentrations of levamisole (i.e., $0.1 \mu \mathrm{M}$ ) was found to reflect an effect of the drug on all cells rather than on a select subpopulation. When cells were counted at different depths of cellulose nitrate filters after $45 \mathrm{~min}$ of migration, it was found not only that the leading front of levamisole-treated cells had migrated farther than had the untreated cells, but also that the majority of cells exposed to levamisole had traveled farther than the untreated cells. This finding is illustrated by a study with normal neutrophils shown in Fig. 1 . By integrating the migration/cell density curves shown in Fig. 1, it was possible to determine the median distance migrated by the neutrophils (indicated by the

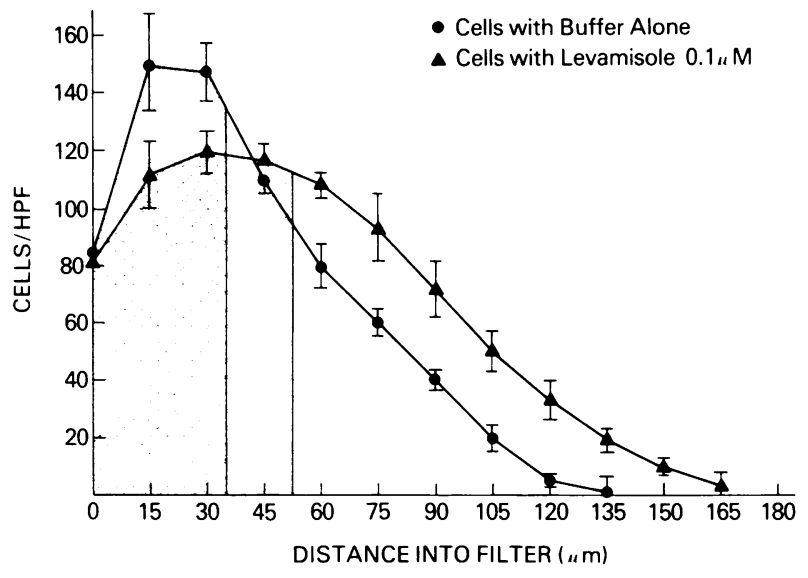

FIGURE 1 Migration of normal neutrophils into a micropore filter during $45 \mathrm{~min}$ in response to $2.5 \%$ activated serum with and without $0.1 \mu \mathrm{M}$ levamisole. Results are expressed as numbers of cells per high-power field at different depths in the filter. Each point represents the mean of eight determinations. SEM are indicated. The area under each curve has been divided in half, and the boundaries between the shaded and nonshaded portions of the curves represent the median migration distances of the two populations of cells with and without levamisole.

shaded and the nonshaded portions of the curves). While the median migration distance of untreated cells was $35 \mu \mathrm{m}$ the median migration distance of cells treated with $0.1 \mu \mathrm{M}$ levamisole was $55 \mu \mathrm{m}$. The differences between these two curves are highly significant $(P<0.001$, Wilcoxin analysis $)$. Comparable data were obtained with neutrophils from the HIE patients.

When normal neutrophils were compared with HIE neutrophils incubated with $0.1 \mu \mathrm{M}$ levamisole, it was found that the migration responses of HIE cells with levamisole were not significantly different from those of normal cells without levamisole $(P>0.20$; Table II, Sections B and C).

Random and directed migration of mononuclear cells from patients and normal volunteers. As was found with neutrophils, the directed migration of mononuclear cells from patients with the HIE syndrome and with $\mathrm{C}-\mathrm{H}$ disease was significantly less than normal $(P<0.05$; Table III, Section A). Unlike neutrophils, significant abnormalities of the random migration of patients' mononuclear cells were not evident, although individual studies suggested that such abnormalities might be present.

Effects of levamisole on mononuclear cell migration in vitro. Enhanced directed migration (chemotaxis) of mononuclear cells from both normal donors and HIE patients was observed when cells were exposed to levamisole at $0.01-1.0 \mu \mathrm{M}$ and at $5.0 \mathrm{mM}$. Although these results were not consistent in every experiment with $0.01-\mu \mathrm{M}, 1.0-\mu \mathrm{M}$, and 5.0-mM doses, levamisole at 0.1

Levamisole and Leukocyte Locomotion 
TABLE III

Mononuclear Cell Migration Responses with and without Levamisole

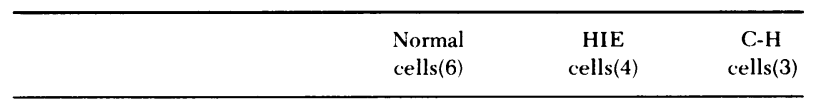

A. Normal and abnormal mononuclear cell migration responses

Directed migration*

(chemotaxis)

Activated random migration*

$88 \pm 13 \ddagger \quad 53 \pm 4$

$39 \pm 9$

Spontaneous random migration*

$38 \pm 7 \quad 27 \pm 8$

$19 \pm 6$

$21 \pm 5 \quad 17 \pm 6$

$13 \pm 3$

B. Effects of levamisole on mononuclear cell directed migration (chemotaxis)

Directed migration*

$\begin{array}{lcll}\text { Without drug } & 88 \pm 13 & 53 \pm 4 & 39 \pm 9 \\ \text { With levamisole } & & & \\ 0.01 \mu \mathrm{M} & 81 \pm 18 & 51 \pm 5 & 36 \pm 10 \\ 0.1 \mu \mathrm{M} & 118 \pm 21 \uparrow & 72 \pm 3 \pi & 39 \pm 6 \\ 1.0 \mu \mathrm{M} & 108 \pm 17 & 76 \pm 6 \pi & 35 \pm 12 \\ 0.1 \mathrm{mM} & 78 \pm 9 & 57 \pm 16 & 43 \pm 15 \\ 5.0 \mathrm{mM} & 96 \pm 8 & 41 \pm 14 & 42 \pm 11\end{array}$

Number of determinations is in parentheses.

* Directed migration (chemotaxis) $=2.5 \%$ endotoxin-activated serum in the stimulus compartment of the assay chambers; activated random migration $=2.5 \%$ endotoxin-activated serum in both the stimulus and cell compartments of the assay chambers; spontaneous random migration = buffer alone in the stimulus compartment of the assay chambers. $\ddagger$ Migration responses expressed as cells/high powered field \pm standard error of the mean.

\$ Concentration of levamisole with cells during assay.

I Difference between migration of levamisole treated cells and migration of cells without drug is significant, $P<0.05$, paired sample $t$ test.

$\mu \mathrm{M}$ consistently improved chemotactic responses of mononuclear cells from both normal donors and HIE patients and stimulation of chemotaxis at this concentration could be shown to be significant by paired sample analysis of pooled data from replicate experiments (Table III, Section B). The abnormal directed migration reponses of mononuclear cells from $\mathrm{C}-\mathrm{H}$ patients were not improved by any of the concentrations of levamisole tested. Also, it was not possible to demonstrate any significant effects of levamisole on the spontaneous or activated random migration of mononuclear cells (data not shown).

Effects of levamisole on neutrophil oxidative metabolism. Studies were undertaken to find if levamisole effects on neutrophil migration could be associated with increased hexose monophosphate shunt activity as has been observed with ascorbic acid (36). As shown in Fig. 2, low concentrations of the drug (in the range of $0.1 \mu \mathrm{M}$ ) significantly stimulated oxida- tive metabolism in both resting and phagocytizing cells. In contrast, high concentrations of drug $(5.0 \mathrm{mM})$ did not enhance but rather inhibited oxidative metabolism.

Effects of levamisole on cyclic nucleotide levels in leukocytes. Because serotonin and ascorbic acid stimulate leukocyte chemotactic responsiveness at concentrations that also raise intracellular cGMP in mononuclear cells (34), we studied the effects of levamisole upon cyclic nucleotide levels in normal leukocytes at concentrations of drug that affect locomotion. Levamisole was not found to alter cAMP levels in either neutrophils or mononuclear cells in any consistent way at any concentration. In neutrophils exposed to levamisole, $0.01-1.0 \mu \mathrm{M}$, elevations in cGMP levels were observed, but these changes were of small magnitude and not statistically significant. However, significant elevations of cGMP were observed in mononuclear cells that had been exposed to levamisole. In the three experiments illustrated in Fig. 3, one mononuclear cell preparation (A), which showed a marked rise of intracellular cGMP in response to serotonin $(0.1 \mathrm{mM})$, also showed significant increases in cGMP when incubated with levamisole at concentrations of 0.01-1.0 $\mu \mathrm{M}$. Cell preparations B and C, which responded less to serotonin, also showed significant increases in cGMP with levamisole but only at a

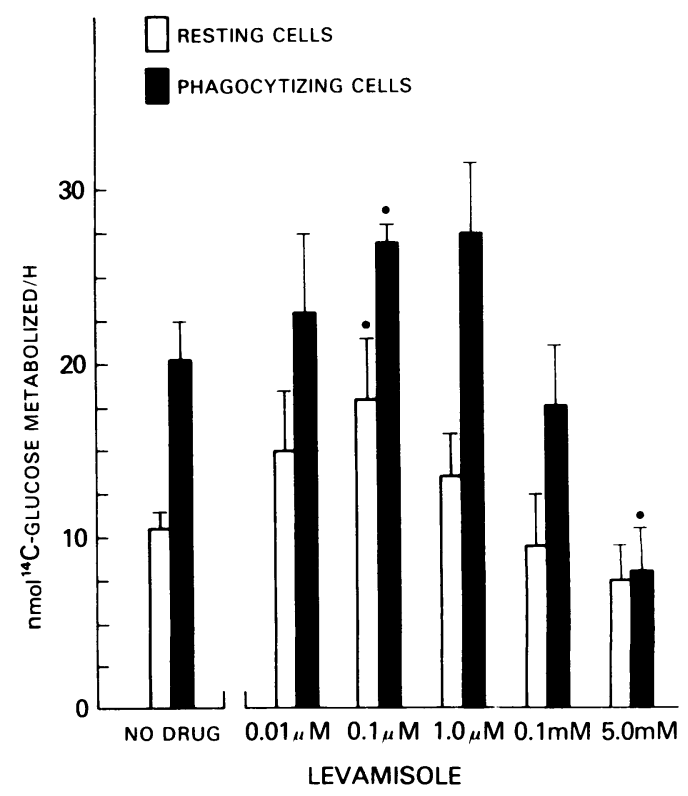

FIGURE 2 Hexose monophosphate shunt activity of resting and phagocytizing neutrophils with varying concentrations of levamisole. Results are expressed as nanomoles ${ }^{14} \mathrm{C}_{1}$-glucose metabolized/2.5 $\times 10^{6}$ cells per $h$ and represent means of four determinations. SEM and $P$ values of significance are indicated (paired sample $t$ test). $P<0.05$, comparison with no drug (O). 
concentration of $0.1 \mu \mathrm{M}$. Since these mononuclear cell preparations contained both monocytes and lymphocytes, we did further studies of levamisole effects on adherent and nonadherent cells separated from mixed mononuclear cell preparations. For these experiments, mononuclear cells were isolated from blood in the usual way and then incubated in Hank's medium (with $10 \%$ fetal calf serum) for $24 \mathrm{~h}$ in plastic Petri dishes. After incubation, nonadherent cells were washed from the dishes. Adherent cells were detached from the plates with a rubber policeman (34). Both adherent and nonadherent cell populations showed increases in cGMP in response to $0.1 \mu \mathrm{M}$ levamisole.

Effects of levamisole on neutrophil surface charge. The chemotactic factors C5a, kallikrein, plasminogen activator, and dialyzable transfer factor have been shown to decrease neutrophil surface charge (35). One agent that inhibited leukocyte chemotaxis, hydrocortisone sodium succinate, prevented the C5a-induced changes in neutrophil surface charge suggesting an effect of this drug at the cell surface (35). To evaluate the possibility that the enhanced migration noted with levamisole was associated with cell surface events, we studied the electrophoretic mobility of neutrophils exposed to levamisole with and without C5a. As shown in Table IV levamisole had no significant effect on C5a-induced changes in surface charge at concentrations of drug that enhanced migration responses. Similarly, levamisole did not alter the surface charge of neutrophils exposed to buffer alone.

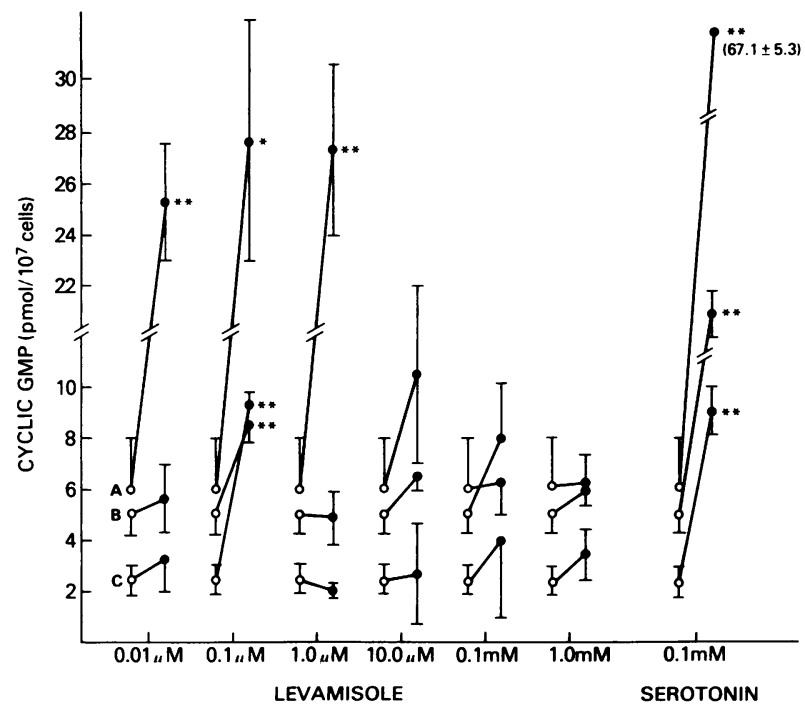

FIGURE 3 cGMP levels in normal mononuclear cells with and without varying concentrations of levamisole. Experiments with three separate mononuclear cell preparations (labeled A, B, and C) are shown. Data points in each experiment are means of three replicate determinations. SEM and significant differences are indicated. Results are expressed as picomoles cGMP/10 ${ }^{7}$ cells. ${ }^{*} P<0.05{ }^{* *} P<0.02$.
TABLE IV

Lack of Effect of Levamisole on C5a-Induced Changes in Surface Charge

\begin{tabular}{lc}
\hline \multicolumn{1}{c}{ Neutrophils* $^{*}$} & Cell surface charge \\
\hline & $\mu \mathrm{m} / \mathrm{s} / \mathrm{V} / \mathrm{cm}$ \\
With buffer alone & $1.95 \pm 0.04$ \\
With C5a & $1.68 \pm 0.08$ \\
With C5a & \\
+ Levamisole $(5.0 \mathrm{mM})$ & $1.73 \pm 0.09$ \\
+ Levamisole $(1.0 \mu \mathrm{M})$ & $1.73 \pm 0.09$ \\
+ Levamisole $(0.1 \mu \mathrm{M})$ & $1.71 \pm 0.07$ \\
+ Levamisole $(0.01 \mu \mathrm{M})$ & $1.72 \pm 0.07$ \\
\hline
\end{tabular}

* Neutrophils $\left(3.0 \times 10^{6} / \mathrm{ml}\right)$ incubated with buffer alone, with $\mathrm{C5a}$, or with C5a and levamisole for $30 \mathrm{~min}$ before surface charge measurements.

† Cell surface charge expressed as micrometers per second per volt per centimeter; results represent means of four experiments; standard errors of means are indicated. Surface charge of cells incubated with buffer alone is different from that of cells incubated with C5a $(P<0.01$, Student's $t$ test); addition of levamisole to C5a-treated cells did not cause significant additional changes in surface charge.

Neutrophil migration responses after exposure to levamisole in vivo. Peak blood levels of 0.5-1.0 $\mu \mathrm{g} / \mathrm{ml}$ levamisole (approximately $0.2-0.4 \mu \mathrm{M}$ ) have been measured within $2 \mathrm{~h}$ after oral ingestion of 1.5 $\mathrm{mg} / \mathrm{kg}$ of the drug in man (37), concentrations of levamisole comparable to those found to enhance the migration responses of leukocytes from the HIE patients in vitro. Four patients with the HIE syndrome were given $150 \mathrm{mg}$ levamisole by mouth at the same time (9 a.m.) on 2 successive days. Blood samples were drawn for studies of neutrophil migration immediately before the first dose and $2 \mathrm{~h}$ after the second dose of levamisole. Neutrophils from two patients (B and $C$ ) were studied before and after two separate courses of levamisole taken $1 \mathrm{wk}$ apart. In addition, neutrophils from a normal volunteer who did not take levamisole were studied concurrently on each day of each experiment. Neutrophil chemotactic responses to casein were evaluated, and within each 2-day experiment, the same preparation of casein was used as the chemotactic stimulus, and the same normal volunteer was used as donor of control cells.

In each of six experiments with the four HIE patients, the chemotactic response (directed migration) of their neutrophils to casein improved after the course of levamisole, both when expressed as absolute values and as percent of responses by normal controls (Fig. 4). In addition it is of interest that with both patients $B$ and $C$ the base-line migration responses of their cells, before taking the drug, were greater $1 \mathrm{wk}$ after the first course of drug than that observed initially (experiments $B_{2}$ and $C_{2}$ compared with $B_{1}$

Levamisole and Leukocyte Locomotion 


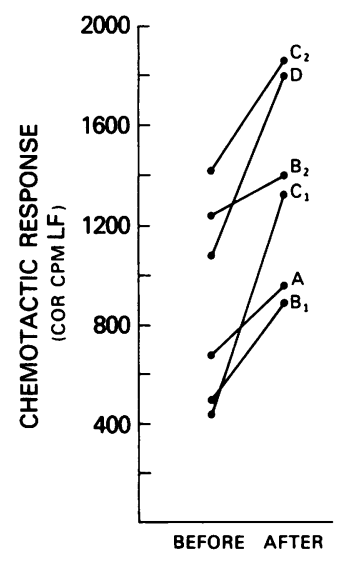

LEVAMISOLE

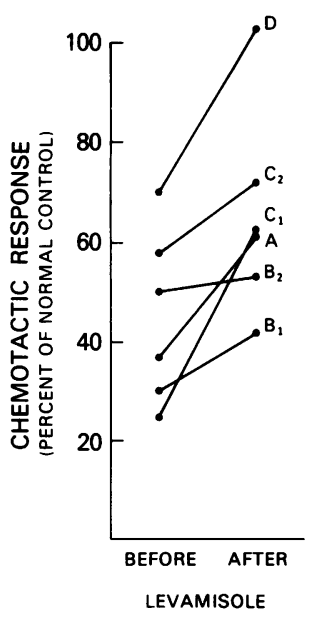

Figure 4 Directed migration (chemotactic) responses of HIE neutrophils to casein before and after exposure to levamisole in vivo. Chemotaxis is expressed as corrected counts per minute lower filter (COR CPM LF) (left panel) and as percent of concurrent normal controls (right panel). For each comparison the same normal subject was used. Increased migration responses are significant by paired sample $t$ test, $P<0.02$. Results obtained with the different patients are indicated. Experiments $B_{2}$ and $C_{2}$ were performed one week after experiments $B_{1}$ and $C_{1}$.

and $\mathrm{C}_{1}$, respectively; these differences were significant, $P<0.01$, by paired sample $t$ test). Furthermore, additional improvement in neutrophil directed migration was noted after these patients took the second course of drug, although the changes were not as great as after the first course. Neutrophil responses to buffer alone, reflecting spontaneous random migration of the cells, were not significantly different before and after the courses of levamisole. The results shown in Fig. 4, which were obtained by the radioassay of neutrophil migration, were confirmed in studies using the morphologic "leading front" assay.

\section{DISCUSSION}

Various agents (ascorbic acid, serotonin, and carbachol) have been shown to stimulate leukocyte locomotion in vitro $(34,36)$. The studies presented in this report, however, are the first to demonstrate pharmacologic improvement of the in vitro migration responses of leukocytes from patients in whom recurrent infection has been attributed to a defect in this leukocyte function (37). Levamisole at concentrations in vitro $(0.1 \mu \mathrm{M})$ that are compatible with blood levels observed after oral administration (38) was found to significantly improve the deficient migration responses of neutrophils and mononuclear cells from four patients with recurrent pyogenic infections and HIE. Neutrophils from these patients also showed improved migration responses after exposure to levamisole in vivo.
Comparable concentrations of levamisole also stimulated migration responses of leukocytes from normal individuals but failed to alter the abnormal directed and random migration of leukocytes of patients with the C-H syndrome.

In a recently reported study (39), (-) tetramisole (levamisole) was shown to enhance normal monocyte chemotaxis at high doses $(1.0 \mathrm{mM})$. We also found significant stimulation of normal monocyte chemotaxis at comparable doses in individual experiments but could not show this effect to be consistent. However, we did find that high concentrations of levamisole (1.0 $\mathrm{mM}$ and above) enhanced neutrophil locomotion, although in an apparently different manner than observed with the effective lower concentrations (0.01$1.0 \mu \mathrm{M})$. The lower concentrations of drug raised leukocyte cGMP levels and stimulated oxidative metabolism in neutrophils; the high concentrations lacked these effects.

The in vitro techniques used in these studies to assess leukocyte chemotaxis necessarily measure several coordinated cellular events, including cell locomotion per se, the sensitivity of cells to a chemotactic factor, and the orientation of cells in response to a gradient of a chemotactic factor. However, by comparing the experimental conditions of directed migration, activated random migration, and spontaneous random migration, it is possible to gain some insight into the manner in which levamisole stimulates leukocyte chemotaxis. At high concentrations of drug $(5.0 \mathrm{mM})$, all forms of leukocyte migration were stimulated, and thus the drug at this concentration appears to affect cell locomotion per se. In contrast, the effective lower concentrations (0.01-1.0 $\mu \mathrm{M})$ were found to stimulate only directed migration and activated random migration, and thus appear to enhance the responsiveness of leukocytes to chemotactic factors and not simply to stimulate cell locomotion per se. The apparent increased sensitivity to chemotactic factors was not, however, reflected by changes in the effects of chemotactic factors upon cell surface charge. This increase in the responsiveness of leukocytes to a chemotactic factor may result from an increased ability of the cells to sense the chemotactic substance and (or) from an increase in the ability of cells to orient themselves. The methods used are unable to distinguish these effects. Our laboratory has recently described a technique of evaluating leukocyte orientation per se (40), and it will be appropriate to reexamine the effects of levamisole on leukocyte migration with such techniques.

By comparing the conditions of random and directed migration, it is also possible to gain some insight into the character of the locomotion abnormalities of $\mathrm{C}-\mathrm{H}$ and HIE leukocytes. The locomotion of C-H leukocytes are abnormal under all conditions, and therefore 
appear to have a basic abnormality in the machinery of cell movement. HIE cells, on the other hand, show abnormal migration responses in the presence of chemotactic factors, but their spontaneous locomotion is normal. These cells thus appear to be deficient in sensing and responding to chemotactic stimuli.

Levamisole has been used empirically as treatment for a variety of diseases other than helminthic infections. Of particular relevance to the present studies is a report of apparent clinical improvement with levamisole therapy in a child with recurrent pyogenic infections, HIE, and mucocutaneous candidiasis (14). However, it is to be emphasized that our studies of leukocyte function in vitro do not show that levamisole will prove to be clinically useful to patients with recurrent infection. Although it may be theoretically attractive to associate recurrent infections with abnormalities of leukocyte locomotion, it cannot be assumed that pharmacologic improvement of this in vitro cell function will lead to clinical benefits. Pursuit of the question of clinical usefulness of levamisole in certain individuals, such as those with HIE syndrome, will require appropriately controlled clinical trials.

Note added in proof. Since submission of this paper, two reports have been published that describe findings similar in part to our own $(41,42)$.

\section{ACKNOWLEDGMENTS}

The authors gratefully acknowledge the expert technical assistance of Mrs. Kathy Ankrom, Mrs. Rhoda Hubert, and Mr. Terrill Smith. The authors also acknowledge the cooperation of Drs. J. Church, L. Frenkel, and J. Bellanti of the Georgetown University School of Medicine, Washington, D. C. and of Dr. B. Wyre of the National Naval Medical Center, Bethesda, Md. for referring patients $B$ and $C$ respectively (Table I) to us for study.

\section{REFERENCES}

1. Thienpont, D., J. Brugmans, K. Abadi, and S. Tanamal. 1969. Tetramisole in the treatment of nematode infections in man. Am. J. Trop. Med. Hyg. 18: 520-525.

2. Gatti, F., F. Kurbwa, J. Vandepitte, and D. Thienpont. 1972. Control of intestinal nematodes in African school children by the trimestrial administration of levamisole. Ann. Soc. Belge. Med. Trop. 52: 19-31.

3. Forsyth, B. A. 1968. The antihelmintic activity of the optical isomers of tetramisole in sheep and cattle. Aust. Vet. J. 44: 395-400.

4. Tripodi, D., L. C. Parks, and J. Brugmans. 1973. Druginduced restoration of cutaneous delayed hypersensitivity in anergic patients with cancer. N. Engl. J. Med. 289: 354-357.

5. Verhaegen, H., J. De Cree, W. De Cock, and F. Verbruggen. 1973. Levamisole and the immune response. N. Engl. J. Med. 289: 1148-1149.

6. Lichtenfeld, J. L., M. Desner, M. R. Mardiney, Jr., and P. H. Wiernik. 1974. Amplification of immunologically induced lymphocyte ${ }^{3} \mathrm{H}$ thymidine incorporation by levamisole. Fed. Proc. 33: 790. (Abstr.)

7. Pabst, H. F., and J. Crawford. 1975. L-tetramisole. En- hancement of human lymphocyte response to antigen. Clin. Exp. Immunol. 21: 468-473.

8. Hadden, J. W., R. G. Coffey, E. M. Hadden, E. LopezCorrales, and G. H. Sunshine. 1975. Effects of levamisole on lymphocyte proliferation and cyclic nucleotide levels. Cell. Immunol. 20: 98-103.

9. Copeland, D., T. Stewart, and J. Harris. 1974. Effect of levamisole (NSC-177023) on in vitro human lymphocyte transformation. Cancer Chemother. Rep. Part 1. 58: $167-170$.

10. Wachi, K. K., L. H. Kimura, S. Perreira, Y. Hokama, S. Perri, and N. Palumbo. 1974. Effect of levamisole and C-reactive protein on mitogen-stimulated lymphocytes in vitro. Res. Commun. Chem. Pathol. Pharmacol. 8: $681-696$.

11. Woods, W. A., M. J. Seigel, and M. A. Chirigos. 1974. In vitro stimulation of spleen cell cultures by poly I: poly $\mathrm{C}$ and levamisole. Cell. Immunol. 14: 327-331.

12. Hoebeke, J., and G. Franchi. 1973. Influence of tetramisole and its optical isomers on the mononuclear phagocytic system. Effect on carbon clearance in mice. $J$. Reticuloendothel. Soc. 14: 317-323.

13. Oliveira Lima, A., M. Q. Javierre, W. Dias Da Silva, and D. Sette Camara. 1974. Immunological phagocytosis: Effects of drugs on phosphodiesterase activity. Experientia (Basel). 30: 945-946.

14. De Cree, J., H. Verhaegen, W. De Cock, R. Vanheule, J. Brugmans, and V. Schuermans. 1974. Impaired neutrophil phagocytosis. Lancet. II: 294-295.

15. Symoens, J., and J. Brugmans. 1974. Treatment of recurrent aphthous stomatitis and herpes with levamisole. Br. Med. J. 4: 592 .

16. Kint, A., and L. Verlinden. 1974. Levamisole for recurrent herpes labialis. N. Engl. J. Med. 291: 308.

17. Chemotaxis: Its Biology and Biochemistry. 1974. In Antibiotics and Chemotherapy. E. Sorkin, editor. S. Karger, Basel, Switzerland. Vol. 19.

18. Gallin, J. I., and S. M. Wolff. 1975. Leukocyte chemotaxis: Physiological considerations and abnormalities. Clin. Haematol. 4: 567-607.

19. Blume, R. S., and S. M. Wolff. 1972. The ChediakHigashi syndrome, studies in four patients and a review of the literature. Medicine (Baltimore). 51: 247-280.

20. Clark, R. A., and H. R. Kimball. 1971. Defective granulocyte chemotaxis in the Chediak-Higashi syndrome. J. Clin. Invest. 50: 2645-2652.

21. Gallin, J. I., J. A. Klimerman, G. A. Padgett, and S. M. Wolff. 1975. Defective mononuclear leukocyte chemotaxis in the Chediak-Higashi syndrome of humans, mink, and cattle. Blood. 45: 863-870.

22. Clark, R. A., R. K. Root, H. R. Kimball, and C. H. Kirkpatrick. 1973. Defective neutrophil chemotaxis and cellular immunity in a child with recurrent infections. Ann. Intern. Med. 78: 515-519.

23. Gallin, J. I. 1975. Abnormal chemotaxis: Cellular and humoral components. In The Phagocytic Cell in Host Resistance. J. A. Bellanti and D. H. Dayton, editors. Raven Press, New York. 227-248.

24. Church, J. A., L. D. Frenkel, D. G. Wright, and J. A. Bellanti. 1976. T lymphocyte dysfunction, hyperimmunoglobulinemia E, recurrent bacterial infections, and defective neutrophil chemotaxis in a Negro child.J. Pediatr. 88: $982-985$.

25. Van Scoy, R. E., H. R. Hill, R. E. Ritts, Jr., and P. G. Quie. 1975. Familial neutrophil chemotaxis defect, recurrent bacterial infections, mucocutaneous candidiasis, and hyperimmunoglobulinemia E. Ann. Intern. Med. 82: 766-771.

Levamisole and Leukocyte Locomotion 
26. Gallin, J. I., R. A. Clark, and H. R. Kimball. 1973. Granulocyte chemotaxis. An improved in vitro assay employing ${ }^{51} \mathrm{Cr}$-labeled granulocytes. J. Immunol. 110: 233-240.

27. Zigmond, S. H., and J. G. Hirsch. 1973. Leukocyte locomotion and chemotaxis: New methods for evaluation and demonstration of a cell-derived chemotactic factor. J. Exp. Med. 137: 387-410.

28. Böyum, A. 1968. Isolation of mononuclear cells and granulocytes from human blood. Isolation of mononuclear cells by one centrifugation, and of granulocytes by combining centrifugation and sedimentation at $1 \mathrm{~g}$. Scand. J. Clin. Lab. Invest. 21 (Suppl. 97): 77-89.

29. Clark, R. A. F., J. I. Gallin, and A. P. Kaplan. 1975. The selective eosinophil chemotactic activity of histamine. J. Exp. Med. 142: 1462-1476.

30. Gallin, J. I., and A. S. Rosenthal. 1974. The regulatory role of divalent cations in human granulocyte chemotaxis. Evidence for an association between calcium exchanges and microtubule assembly. J. Cell Biol. 62: 594-609.

31. Snyderman, R., L. C. Altman, M. S. Hausman, and S. E. Mergenhagen. 1972. Human mononuclear leukocyte chemotaxis: A quantitative assay for humoral and cellular chemotactic factors. J. Immunol. 108: 857-860.

32. Mickenberg, I. D., R. K. Root, and S. M. Wolff. 1970. Leukocyte function in hypogammaglobulinemia. J. Clin. Invest. 49: 1528-1538.

33. Steiner, A. L., C. W. Parker, and D. M. Kipnis. 1972. Radioimmunoassay for cyclic nucleotides. I. Preparation of antibodies and iodinated cyclic nucleotides. J. Biol. Chem. 247: 1106-1113.

34. Sandler, J. A., J. I. Gallin, and M. Vaughn. 1975. Effects of serotonin, carbamylcholine and ascorbic acid on leukocyte cyclic GMP and chemotaxis. J. Cell Biol. 67: 480-484.

35. Gallin, J. I., J. R. Durocher, and A. P. Kaplan. 1975. Interaction of leukocyte chemotactic factors with the cell surface. I. Chemotactic factor-induced changes in human granulocyte surface charge. J. Clin. Invest. 55: 967-974.

36. Goetzl, E. J., S. I. Wasserman, I. Gigli, and K. F. Austen. 1974. Enhancement of random migration and chemotactic response of human leukocytes by ascorbic acid. J. Clin. Invest. 53: 813-818.

37. Hill, H. R., H. D. Ochs, P. G. Quie, R. A. Clark, H. F. Pabst, S. J. Klebanoff, and R. J. Wedgwood. 1974. Defect in neutrophil granulocyte chemotaxis in Job's syndrome of recurrent "cold" staphylococcal abscesses. Lancet. II: 617-619.

38. Report of pharmacology of L-tetramisole. 1974. From Janssen Pharmaceutica Research Laboratories, Beerse, Belgium. Unpublished report.

39. Pike, M. C., and R. Snyderman. 1976. Augmentation of human monocyte chemotactic response by levamisole. Nature (Lond.). 261: 136-137.

40. Malech, H. L., R. K. Root, and J. I. Gallin. 1976. Centriole, microtubule and microfilament orientation during human polymorphonuclear leukocyte (PMN) chemotaxis (CTX). Clin. Res. 24: 314A.

41. Anderson, R., A. Glover, H. J. Koornhof, and A. R. Rabson. 1976. In vitro stimulation of neutrophil motility by levamisole: maintainance of cGMP levels in chemotactically stimulated levamisole-treated neutrophils. J. Immunol. 117: 428-432.

42. Schmidt, M. E., and S. D. Douglas. 1976. Effects of levamisole on human monocyte function and immunoprotein receptors. Clin. Immunol. Immunopathol. 6: 299-305. 